\title{
Influence of the microbiological quality of raw milk on the shelf life of pasteurized milk
}

\section{Influência da qualidade microbiológica do leite cru na vida útil do leite pasteurizado}

\author{
José Carlos Ribeiro Júnior ${ }^{1 *}$; Aline Marangon de Oliveira ${ }^{2}$; Fernando de Godoi \\ Silva $^{3}$; Lorena Natalino Haber Garcia ${ }^{4}$; Cátia Maria de Oliveira Lobo ${ }^{1}$; \\ Bruna Alexandrino ${ }^{1}$; Ronaldo Tamanini ${ }^{5}$; Vanerli Beloti ${ }^{5}$
}

\begin{abstract}
The dairy industry strives to produce high quality products with high nutritional value as well as to meet the legal standards for longer shelf life. However, these goals are made unfeasible by the poor quality of raw milk produced in some regions of Brazil. Others Brazilian dairy regions, however, already succeed in producing milk with low microbial counts, such as the municipality of Castro, Paraná state, designated as the 'Brazilian dairy capital'. In order to evaluate the effect of raw milk quality on microbial counts during the shelf life of pasteurized milk, samples were collected from two dairy regions of Paraná: the northern and Castro region, characterized by milk production with high and low microbiological counts, respectively. Samples were experimentally pasteurized and the total microorganism counts were analyzed for 18 days at $7{ }^{\circ} \mathrm{C}$, using the Brazilian standard microbiological count limit for pasteurized milk $\left(8 \times 10^{4} \mathrm{CFU} / \mathrm{mL}\right)$ as the end of the shelf life. Low microbiological counts in raw milk (Castro) resulted in significantly lower counts shortly after pasteurization and over the entire shelf life, meeting the pasteurized milk standard for 18 days. The temporal evolution in the counts over 18 days for the milks of high and low microbiological count was similar; however, the disparity between the absolute counts between the regions was significant $(\mathrm{p}<0.05)$. Of the milk samples from northern Paraná, four (44.4\%) already had counts higher than that of the legislative limit for pasteurized milk immediately after pasteurization. The others (five) reached the maximum microbiological count limit for pasteurized milk on the $6^{\text {th }}$ day after pasteurization. In contrast, the milk from the Castro region remained below the limit throughout the analysis period. Thus, it can be stated that the microbiological quality of raw milk is directly related to the initial count of microorganisms after pasteurization, and that pasteurized milk produced from raw milk with low microbiological counts complies with the Brazilian legislation for 18 days following thermal processing.
\end{abstract}

Key words: Durability. Shelf life. Thermoduric. Total bacterial count.

\footnotetext{
1 Drs. em Ciência Animal, Profs., Escola de Medicina Veterinária e Zootecnia, Universidade Federal do Tocantins, UFT, Araguaína, TO, Brasil. E-mail: jcribeiro@uft.edu.br; cmolobo@uft.edu.br; bralexandrino@uft.edu.br

2 M.e em Ciência Animal, Doutoranda em Zootecnia, Universidade Federal de Viçosa, UFV, Viçosa, MG, Brasil. E-mail: alinemarangonvet@gmail.com

3 M.e em Ciência de Alimentos, Universidade Estadual de Londrina, UEL, Londrina, PR, Brasil. E-mail: fgodois18@gmail.com

4 Especialista em Inspeção de Produtos de Origem Animal, Discente de Mestrado em Medicina Veterinária, Universidade Federal de Viçosa, UFV, Viçosa, MG, Brasil. E-mail: lorenanhg@hotmail.com

5 Pesquisadores, Instituto Nacional de Ciência e Tecnologia para a Cadeia Produtiva do Leite, INCT, Cadeia do Leite, UEL, Londrina, PR, Brasil. E-mail: ronaldotamanini@gmail.com; vanerlib@gmail.com

* Author for correspondence
} 


\section{Resumo}

Produtos de alta qualidade, com elevado valor nutricional e longa vida útil, são objetivos almejados pela indústria de laticínios, dificultados pela má qualidade microbiológica do leite cru produzido no Brasil. No entanto, algumas regiões já produzem leite com baixas contagens microbianas, como a capital brasileira do leite, Castro, no Paraná. Com a intenção de avaliar o efeito da qualidade do leite cru nas contagens microbianas durante o período de vida útil de leite pasteurizado, amostras de leite cru foram coletadas de duas regiões do Paraná: a região norte e a região de Castro, caracterizadas pela produção de leite com contagens microbiológicas altas e baixas, respectivamente. As amostras foram experimentalmente pasteurizadas e analisadas as contagens totais de micro-organismos pelo período de 18 dias a $7^{\circ} \mathrm{C}$, utilizando o padrão determinado na IN62/2011 para o fim da vida de útil (máx. $8 \times 10^{4}$ $\mathrm{UFC} / \mathrm{mL}$ ). Baixas contagens microbiológicas no leite cru resultaram em contagens significativamente menores logo após a pasteurização e ao longo da vida útil, atendendo ao padrão de qualidade para leite pasteurizado por 18 dias. As evoluções nas contagens durante o período de análise para os leites de alta e baixa contagem microbiológica foram proporcionais, no entanto, a disparidade entre as contagens absolutas entre as regiões foi significativa. O leite do norte do Paraná atingiu o limite máximo para o leite pasteurizado no $6^{\circ}$ dia após a pasteurização, enquanto o leite da região de Castro manteve-se abaixo da contagem limite durante todo o período de análise. Dessa forma, é possível afirmar que as contagens de microrganismos e a vida útil do leite pasteurizado está diretamente relacionada às contagens apresentadas pelo leite antes da pasteurização. Assim, para prolongar a vida útil do leite pasteurizado, deve-se diminuir as contagens do leite cru e, como se sabe, as boas práticas de higiene na produção são essenciais para atingir esse objetivo.

Palavras-chave: Contagem bacteriana total. Durabilidade. Termodúricos. Vida de prateleira.

\section{Introduction}

There is a worldwide demand for dairy products of high quality, high nutritional value, and long shelf life; factors which facilitate the logistics of their widespread distribution. The rapid perishability of Brazilian pasteurized milk causes losses in the market due to failure to qualify as ultra high temperature (UHT) milk, which has a longer shelf life. Increasing the quality of pasteurized milk and ensuring a longer shelf life are challenges which the Brazilian dairy industry must overcome to increase the scope of marketing and boost milk consumption (FROMM; BOOR, 2004).

Intrinsic milk characteristics and composition, as well as extrinsic factors, such as microbial contamination, are key determinants in the quality of the raw milk and, consequently, in the shelf life of the processed product. The microbial load, the identity of the predominant microorganisms, the somatic cell count, and the storage conditions of the raw milk, can all interfere in the perishability of the product and its potential for an extended shelf life
(ANTUNES, 2014).

The initial microbiota of milk consists of bacteria and fungi that colonize the udder and contaminants introduced during milking, storage, and processing. Lactic bacteria, pathogens, and spoilage microorganisms may be present in raw milk in varying proportions depending on the level of hygiene maintained during its preparation. Due mainly to the lack of good hygiene practices in the milking process, raw milk produced in much of Brazil has high microbial counts and, consequently, low technological potential and short shelf life (BELOTI, 2015).

Despite this, some dairy regions of Brazil produce milk with excellent microbiological quality, due to motivation by payment programs for dairy quality, and with high investment in technology applied to production, quality, and animal breeding (RIBEIRO JÚNIOR et al., 2015; 2018a). The city of Castro, for example, is recognized for its high production and quality of milk, being recently recognized as the 'Brazilian dairy capital' (BRASIL, 2017a). 
However, most milk producing regions in the country have little investmentand still face difficulties in maintaining the standards of production required by Brazilian raw and pasteurized milk quality law (BRASIL, 2011).

Regardless of the initial contamination of raw milk, the thermal treatment process of pasteurization, which is obligatory in Brazil (BRASIL, 2017b), efficiently eliminates all pathogenic microorganisms and most of the saprophytic microbiota, with minimal alteration of the milk's composition (BELOTI, 2015). This thermal treatment guarantees food safety, but does not involve complete sterilization, thus the milk retains some microorganisms capable of multiplication as well as preformed enzymes that deteriorate the product (MENEZES et al., 2014; RIBEIRO JÚNIOR et al., 2018b). According to Nascentes and Araújo (2012), there is a direct correlation between the microorganism counts in raw and processed milk; thus, the initial low quality may be detrimental to the attributes of the product and the determination of shelf life.

Considering the differences in the quality of refrigerated raw milk and the low shelf life of Brazilian pasteurized milk, the present study aimed to verify the impact of the total bacterial counts of raw milk from two dairy regions in the state of Paraná on the shelf life of the resulting pasteurized milk.

\section{Materials and Methods}

Samples of raw milk were collected from nine large dairy farms in the Castro region (the central eastern region of Paraná) and nine small farms in the north and northwestern regions of Paraná, totaling 18 milk samples. These properties have already been previously characterized (RIBEIRO JÚNIOR et al., 2015; 2018a). The collections were aseptically performed from May 2016 to August 2017, transported under refrigeration and promptly analyzed in the Laboratório de Inspeção de Produtos de Origem Animal (LIPOA), a member of the Instituto Nacional de Ciência e Tecnologia para a Cadeia Produtiva do Leite at the Universidade Estadual Londrina, Paraná state, Brazil.

To avoid the presence of microbial growth inhibitory substances, which could negatively influence microbiological counts, and as a screening model, all raw milk samples were submitted to lactofermentation according to BEHMER (1999) in parallel to the microbiological analysis. All the milk samples used in the present study displayed some type of clot in lactofermentation.

The raw milk samples were serially diluted in sterile saline solution to the mesophilic aerobic counts in Petrifilm AC (3M Microbiology, St. Paul, MN, USA) according to the manufacturer's recommendations. The samples were subsequently submitted to the experimental pasteurization process ( $62 \pm 0.5^{\circ} \mathrm{C} / 30 \mathrm{~min}$ ) according to Standard Methods for Examination of Dairy Products (FRANK; YOUSEF, 2004).

To evaluate the shelf life of pasteurized milk, $5 \mathrm{~mL}$ aliquots were transferred to tubes (10 tubes per sample) and refrigerated at $7{ }^{\circ} \mathrm{C}$. Every two days (for a total of 18 days), a random aliquot of each sample was evaluated for total bacterial count by seeding serial dilutions onto agar plates, and counting colony forming units (CFU) after 48 hours of incubation at $35^{\circ} \mathrm{C}$.

For analysis of the results, the counts were converted into $\log \mathrm{CFU} / \mathrm{mL}$, and data were submitted to analysis of variance (ANOVA) tests using a completely randomized model. The $t$ test was used when necessary to compare the means using the R software (https://www.r-project.org/). A significance level of 5\% probability was adopted.

\section{Results and Discussion}

The initial bacterial counts of the raw milk samples displayed significant differences $(p<0.05)$ among the regions of the Paraná state evaluated. The milk samples from the dairy farms of Castro (central 
eastern Paraná) presented significantly lower mean values $(1.93 \pm 0.51 \log \mathrm{CFU} / \mathrm{mL})$ than those obtained in raw milk from the north-northwest region (4.7 \pm $0.68 \log \mathrm{CFU} / \mathrm{mL}$ ), as shown in Figure 1.

The differences observed by the present study in the quality of raw milk samples from the two regions was also described by the study of Ribeiro Júnior et al. (2015). The previous study reported that the microbiological counts of milk from large (Castro) and small (north and northwest) producers of the state of Paraná varied significantly from 4.18 $\log \mathrm{CFU} / \mathrm{mL}$ to $6.58 \log \mathrm{CFU} / \mathrm{mL}$, respectively.

Figure 1. Total bacterial count of raw milk obtained from dairy farms in the north-northwest and central-eastern regions (Castro) of Paraná state, Brazil.

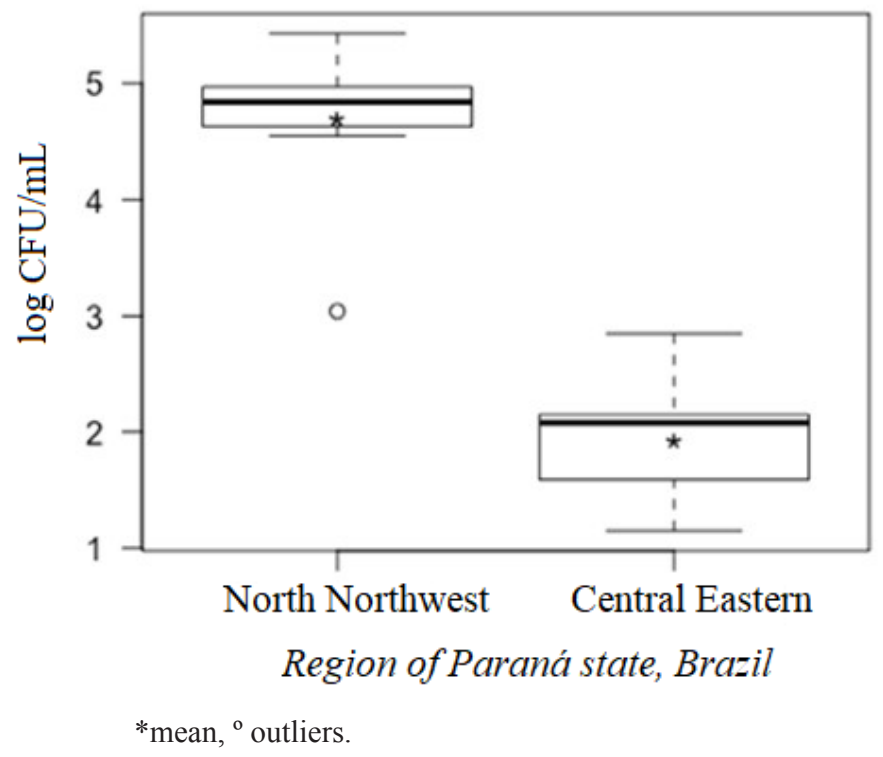

High initial counts of microorganisms indicate poor quality of the raw milk obtained in the northnorthwest region of Paraná, probably due to hygiene failures in the process of obtaining milk (VALLIN et al., 2009). According to Guerreiro et al. (2005), good hygienic practices, applied prophylactically, can significantly reduce bacterial counts in refrigerated raw milk. The authors identified initial microorganism counts of $6.54 \log \mathrm{CFU} / \mathrm{mL}$ in raw milk from properties with a considerable technological level of production, which was higher than the counts of properties performing manual milking. In this way, they verified that the technological level used in obtaining the milk is not necessarily related to the microbiological quality and that mechanical milking can be a source of contamination when hygiene and cleaning procedures are not properly employed. Thus, it can be inferred that the best quality of raw milk from properties in the Paraná central region is mainly a result of the intensive use of good hygiene practices.

The evolution of total bacterial counts throughout the shelf life was also significantly different between the two regions studied $(p<0.05)$ (Figure 2 ). It is notable that samples of pasteurized milk produced from raw milk with high microbiological counts (north-northwest) of Paraná reached the maximum limit of microorganisms (4.9 log CFU/ $\mathrm{mL}$, corresponding to $8 \times 10^{4} \mathrm{CFU} / \mathrm{mL}$ ) established by IN62 of MAPA (BRASIL, 2011), after six days of storage at $7^{\circ} \mathrm{C}$. However, the milk from the Castro region complied with the legislative requirements for microbiological counts of pasteurized milk during the entire refrigeration period (18 days). 
Notably, 4 (44.4\%) of the nine milk samples from the north-northwest producers of Paraná already had counts higher than that of the legislative limit for pasteurized milk immediately after pasteurization (day 0), ranging from 5.9 to $8.5 \log \mathrm{CFU} / \mathrm{mL}$. This suggests that a significant proportion of the contaminating microorganisms of this raw milk are thermoduric.
Our results showed that the samples of raw milk of higher contamination generated samples of pasteurized milk with higher microbiological counts immediately after thermal processing (day 0 , Figure 2). These results corroborate the theory that the total microbiological count of refrigerated raw milk directly influences the counts, and therefore the shelf life, of the resulting pasteurized milk.

Figure 2. Comparison between the raw milk total microorganism counts from the central and north regions of Paraná state, Brazil, analyzed during the whole period of the shelf life (18 days).

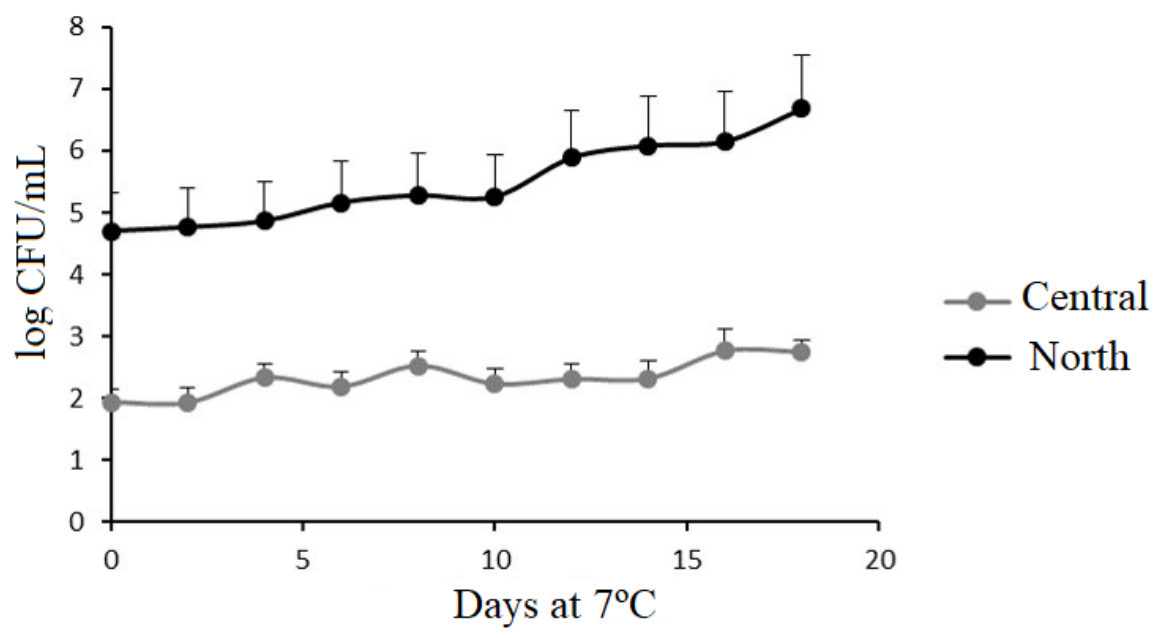

Figure 2 shows that pasteurized milk obtained from the Castro region, even after 18 days of storage under refrigeration $\left(7^{\circ} \mathrm{C}\right)$, still has significantly lower total counts of microorganisms $(p<0.05)$ than those detected in the samples of the north-northwest of Paraná on the first day after pasteurization.

The initial quality of raw milk is therefore a major determinant of the shelf life of the processed product, since thermoduric microorganisms which resist pasteurization, and thermostable enzymes produced by psychrotrophs, remain active in milk, and can cause sensory alterations (REIS et al., 2013; MURPHY et al., 2016; RIBEIRO JÚNIOR et al., 2018b). Thus, the pasteurized milk shelf life is determined by the number of spoilage psychrotrophic microorganisms as well as the number of thermoduric microorganisms in raw milk, as some species fall into both descriptions (BELOTI, 2015).

Other factors may also influence the shelf life of pasteurized milk, such as packaging (PETRUS et al., 2010), pasteurization temperature (RANIERI et al., 2009), and somatic cell counts (SCC). The latter, in particular, is correlated with the activity of endogenous proteases of milk, such as plasmin, which has particularly noticeable effects on milk with high microbiological counts (GARGOURI et al., 2013; MURPHY et al., 2016), such as that found in the central region of Paraná.

The study of Ribeiro Júnior et al. (2015) showed that the milk of large producers in the Castro region has significantly higher mean SCC than the small producers in the northern region of Paraná $\left(3.9 \times 10^{5}\right.$ 
and $2.2 \times 10^{5} \mathrm{SC} / \mathrm{mL}$, respectively). This is expected since pure, high-producing animals, characteristic of large dairy farms, are more susceptible to infections of the mammary gland. However, this higher milk cellularity of the major producers in the region apparently does not influence the shelf life of pasteurized milk in relation to the bacterial count.

The present work verified that the quality of raw milk is essential for determining the shelf life of the pasteurized product. In addition, raw milk with low microbiological quality demands the application of good hygiene practices during milk collection. The quality of the milk produced in the Castro region qualifies it for the production of pasteurized milk with a long shelf life, similar to that practiced in the United States.

\section{Conclusion}

The shelf life of pasteurized milk is inversely proportional to the microbiological count of the milk in its raw form, based on the results of this sample unit. In particular, the thermoduric microorganisms present in raw milk influence the shelf life of pasteurized milk. The best way to increase the quality, shelf life, and consequently the logistics process of pasteurized milk is to reduce the incorporation of microorganisms into raw milk by practicing good hygiene during the initial collection and storage processes.

\section{References}

ANTUNES, V. C. Uso de microfiltração para melhoria da qualidade e extensão da vida de prateleira de leite pasteurizado. Brazilian Journal of Food Technology, Campinas, v. 17, n. 1, p. 75-86, 2014.

BEHMER, M. L. A. Tecnologia do leite. São Paulo: Editora Noel, 1999. 322 p.

BELOTI, V. Leite: obtenção, inspeção e qualidade. Londrina: Editora Planta, 2015. 417 p.

BRASIL. Casa Civil da Presidência da República. Lei 13. 584/2017 - Confere ao município de Castro, no estado do Paraná, o título de capital nacional do leite. Diário
Oficial [da] União, Brasília, 26 dez. 2017a, p. 6.

BRASIL. Ministério da Agricultura, Pecuária e Abastecimento. Decreto N 9013, de 29 de março de 2017. Regulamento da Inspeção Industrial e Sanitária de Produtos de Origem Animal (RIISPOA). Diário Oficial [da] República Federativa do Brasil, Brasília, 29 de março de 2017b.

BRASIL. Ministério da Agricultura, Pecuária e Abastecimento. Instrução Normativa 62, de 29 dez. 2011. Aprova o regulamento técnico de produção, identidade e qualidade do leite tipo a o regulamento técnico de identidade e qualidade de leite cru refrigerado, o regulamento técnico de identidade e qualidade de leite pasteurizado e o regulamento técnico da coleta de leite cru refrigerado e seu transporte a granel. Diário Oficial [da] República Federativa do Brasil, Brasília, 30 dez. 2011.

FRANK, J. F.; YOUSEF, A. E. Tests for groups of microganisms. In: WHER, H. M.; FRANK, J. F. (Ed.). Standard methods for the examination of dairy products. $17^{\text {th }}$ ed. Washington: American Public Health Association, 2004. Chap. 8, p. 227-248.

FROMM, H. I.; BOOR, K. J. Characterization of pasteurized fluid milk shelf-life attributes. Journal of Food Science, Chicago, v. 69, n. 8, p. 207-214, 2004.

GARGOURI, A.; HAMED, H.; ELFEKI, A. Analysis of raw milk quality at reception and during cold storage: combined effects of somatic cell counts and psychrotrophic bacteria on lipolysis. Journal of Food Science, Chicago, v. 78, n. 9, p. 1405-1411, 2013.

GUERREIRO, P. K.; MACHADO, M. R. F.; BRAGA, G. C.; GASPARINO, E.; FRANZENER, A. S. M. Qualidade microbiológica em função de técnicas profiláticas no manejo de produção. Ciências Agrotécnicas, Lavras, v. 29 , n. 1, p. 216-222, 2005

MENEZES, M. F.; SIMEONI, C. P.; BORTOLUZZI, D.; HUERTA, K.; ETCHEPERE, M.; MENEZES, C. Microbiota e conservação do leite. Revista Eletrônica em Gestão, Educação e Tecnologia Ambiental, Santa Maria, v. 18, n. 5, p. 76-89, 2014.

MURPHY, S. C.; MARTIN, N. H.; BARBANO, D. M.; WIEDMANN, M. Influence of raw milk quality on processed dairy products: How do raw milk quality test results relate to product quality and yield? Journal of Dairy Science, Madison, v. 99, n. 12, p. 10128-10149, 2016. DOI: $10.3168 /$ jds.2016-11172

NASCENTES, R. M.; ARAÚJO, B. C. de. Comparação da qualidade microbiológica de leite cru, pasteurizado e UHT comercializados na cidade de Patos de Minas, MG. Perquirere, Patos de Minas, v. 9, n. 1, p. 212-223, 2012 
PETRUS, R. R.; LOIOLA, C. G.; OLIVEIRA, C. A. F. Microbiological shelf life of pasteurized milk in bottle and pouch. Journal of Food Science, Chicago, v. 75, n. 1, p. 36-40, 2010. DOI: 10.1111/j.1750-3841.2009.01443.x

RANIERI, M. L.; HUCK, J. R.; SONNEN, M.; BARBANO, D. M.; BOOR, K. J. High temperature, short time pasteurization temperatures inversely affect bacterial numbers during refrigerated storage of pasteurized fluid milk. Journal of Dairy Science, Madison, v. 92, p. 48234832, 2009. DOI: $10.3168 /$ jds.2009-2144

REIS, K. T. M.; SOUZA, C. H. B.; SANTANA, E. H. W.; ROIG, S. M. Qualidade microbiológica do leite cru e pasteurizado produzido no Brasil: Revisão. UNOPAR Científica Ciências Biológicas e da Saúde, Londrina, v. 15, n. 10, p. 411-421, 2013.

RIBEIRO JÚNIOR, J. C.; OLIVEIRA, A. M.; SILVA, F. G.; TAMANINI, R.; OLIVEIRA, A. L. M.; BELOTI, V. The main spoilage-related psychrotrophic bacteria in refrigerated raw milk. Journal of Dairy Science, Madison, v. 101, n. 1, p. 75-83, 2018a. DOI: $10.3168 /$ jds.2017-13069
RIBEIRO JÚNIOR, J. C.; TAMANINI, R.; OLIVEIRA, A. L. M.; ALFIERI, A. A.; BELOTI, V. Genetic diversity of thermoduric spoilage microorganisms of milk from Brazilian dairy farms. Journal of Dairy Science, Madison, v. 101, n. 8, p. 6927-6936, 2018b. DOI: $10.3168 /$ jds. $2017-13948$

RIBEIRO JÚNIOR, J. C.; TAMANINI, R.; SILVA, L. C. C.; BELOTI, V. Quality of milk produced by small and large dairy producers. Semina: Ciências Agrárias, Londrina, v. 36, n. 2, p. 883-888, 2015. DOI: $10.5433 / 1679-0359.2015 \mathrm{v} 36 \mathrm{n} 2 \mathrm{p} 883$

VALLIN, V. M.; BELOTI, V.; BATTAGLINI, A. P.; TAMANINI, R.; FAGNANI, R.; ANGELA, H. L.; SILVA, L. C. C. Melhoria da qualidade do leite a partir da implantação de boas práticas de higiene na ordenha em 19 municípios da região central do Paraná. Semina: Ciências Agrárias, Londrina, v. 30, n. 1, p. 181-188, 2009. 
